\title{
Environmental risk assessment of cement dust on soils and vegetables in an urban city of South Western Nigeria
}

\author{
T. A. Laniyan ${ }^{1}$, A. S. Olatunji ${ }^{2}$ \& O. G. Fagade ${ }^{2}$ \\ ${ }^{I}$ Department of Earth Sciences, Olabisi Onabanjo University, Nigeria \\ ${ }^{2}$ Geology Department, University of Ibadan, Nigeria
}

\begin{abstract}
The negative consequence of industries in urban cities has become a major concern. Environmental risk assessment of heavy metals in the cement factories around Ewekoro environ was evaluated to deduce its risk on public health.

Soil samples and consumable vegetables (Sugar-cane (Saccharumofficinarum), Soko (Celosia argentea), Cocoyam (Colocasiaesculerita) and Ewedu (Corchoruos olitorius) were collected $200 \mathrm{~m}$ apart around the cement factory. Soil samples were dis-aggregated and sieved through a $65 \mu$ mesh sieve, then analyzed using inductively coupled plasma-emission spectrometry (ICP-ES), while plant samples were crushed and pulverized before being analysed using inductively coupled plasma-mass spectrometry (ICP-MS), all analyses were done at Acme laboratories Canada. Geochemical result of soils showed that most of the metals have values above the USEPA standard except $\mathrm{Ni}, \mathrm{V}, \mathrm{Cr}$, and $\mathrm{Ba}$, due to the effect of cement factory. Contamination factor and degree $\left(\mathrm{C}_{\mathrm{deg}}\right)$ revealed extreme contamination of $\mathrm{Zn}$ and $\mathrm{Mn}$. Inter elemental analysis showed a strong correlation between $\mathrm{Cr}-\mathrm{As}(' \mathrm{r}$ ' $=0.872$ ) and Ga-v (' $r$ ' $=0.936$ ), which reflects the same anthropogenic source. Geochemical results in vegetables revealed $\mathrm{Zn}$ to be the highest metal accumulated, and that which is most contaminated is Ewedu (Corchoruos olitorius). A strong and positive correlation was found in $\mathrm{Ba}-\mathrm{Sr}$, and $\mathrm{Cd}-\mathrm{Zn}$ with $\mathrm{r}>0.9$ showing the same anthropogenic source.Transfer factor(TF) revealed accumulation of metals by the vegetables. Analysis of the health implications of these heavy metals was carried out in some clinics around the area and the common diseases recorded are the ones generally associated with cement dust inhaling. Soils and vegetables
\end{abstract}


of areas around the cement factory are contaminated with metals especially $\mathrm{Zn}$ and $\mathrm{Mn}$, with a severe effect on the public health.

Keywords: transfer factor, geo-accumulation index, contamination, vegetables, anthropogenic.

\section{Introduction}

Clean air, water and soil are becoming increasingly precious resources in the world [1] owing to high rate of pollution and contamination of the soil, water, and air which somehow has become inevitable as a result of several anthropogenic activities. Environmental pollution by toxic metals has increased steadily since the industrial revolution, thereby causing serious ecological problems [2, 3]. Significant amounts of heavy metals and other chemicals are introduced into the environment particularly by industries amongst which the Cement Industry is a major player [4-6]. Cement manufacturing plants are known to produce a number of emissions which include particulate matter, gases and various heavy metals that are hazardous to the biotic environment with their impact often clearly manifested on soil and plants in addition to terrestrial and aquatic flora and fauna [7-10]; consequently affecting food quality and human health $[11,12]$. This work is aimed at evaluating the environmental impact of a major cement factory on the surrounding soils and cultivated vegetables.

\subsection{Location and accessibility}

The study area is Ewekoro, a community in the south-western part of Nigeria. It is defined by the geographical co-ordinates of Longitude $3^{\circ} 12^{\mathrm{I}} 4^{\mathrm{II}}-3^{\circ} 13^{\mathrm{I}} 6^{\mathrm{II}}$ and Latitude $06^{\circ} 52^{\mathrm{I}} 80^{\mathrm{II}}-06^{\circ} 54^{\mathrm{I}}$ (Fig. 1). The town hosts one of the biggest cement factories in Nigeria.

\section{Method}

\subsection{Project Set-up}

A random sampling technique was used for the field exercise. The factory was made the central point while profile lines of about $2 \mathrm{~km}$ long were defined to the east, west, north and south of the factory respectively. Soil and plants samples were taken along the defined profiles from farmland surrounding the cement factory (Fig. 1). Soil samples were collected at depths ranging from 3-5cm using a hand trowel. Cultivated edible plants sampled were corchorous olitorious, solarium lycopersicum, saccharum officinanum and celosia argentea. The soil samples were put into clean polythene bags while the plants were carefully wrapped in Kraft paper. The soils were air dried and disaggregated. Litters and debris were then removed from the soil by sieving with a $2 \mathrm{~mm}$ mesh sieve. The 
plant were similarly dried and blended to shaft. The sieved soils and blended plants were then digested and analysed for metal contents using Inductively Coupled Plasma-mass Spectrometry (ICP-MS). The medical records of the various health Center within the town were collated to ascertain the prevalent diseases in the town.

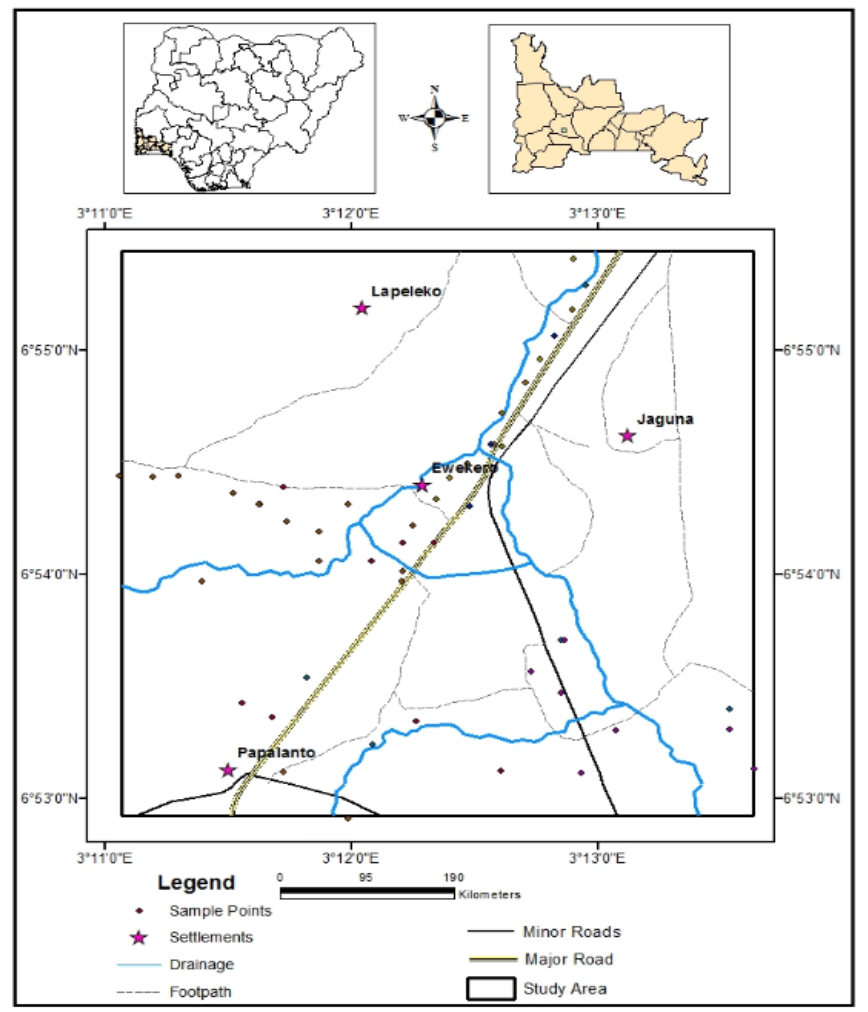

Figure 1: Location and Sampling Point Distribution in the study area.

\section{Results and discussions}

\subsection{Metal concentration in the soils and vegetable}

The geochemical results of soil and plants samples are presented in Table 1. The various values obtained for the selected metals were compared to standard guidelines to ascertain whether the soils and plants have aggregated the metals or not [15]. All the metals except $\mathrm{Mn}$ and $\mathrm{Ba}$ were found to be above the limit in most of the analysed samples. The range of concentrations of metals in the soil is in the order $\mathrm{Zn}<\mathrm{Cu}<\mathrm{Pb}<\mathrm{Ba}<\mathrm{Mn}$, while that of the vegetables is $\mathrm{Mn}>\mathrm{Zn}>$ $\mathrm{Ba}>\mathrm{Cr}>\mathrm{Cu}>\mathrm{Pb}>\mathrm{Ni}>\mathrm{Cd}$. $\mathrm{Zn}, \mathrm{Cu}, \mathrm{Pb}$ and $\mathrm{Cd}$ were observed to be above the 
permissible levels for both the soils and the plants samples. Mn was observed to be above guidelines levels in some samples but alongside $\mathrm{Ba}$ and $\mathrm{Ni}$ was within permissible levels for most of the soil and sand samples (Table 1).

\subsubsection{Contamination and transfer factors}

To ascertain the effects of the concentration on the various media (soils and plants) the contamination and transfer factors were also evaluated. Contamination factor $\left(\mathrm{C}_{\mathrm{f}}\right)$ (Table 2) was used to determine the impact of each metal on soil quality and was calculated using the equation: $C_{f}=C_{n} / B_{n}$. Where $C_{n}$ represent the measured concentration in geologic media and $B_{n}$ is the local background value concentration of metal. The various values were then used to classify the soils according to [13]. Table 2 list the various ranges of values calculated for the Contamination factors of the soils in the Ewekoro area. The Transfer Factor $\left(\mathrm{T}_{\mathrm{f}}\right)$ is the measure of bio-accumulation or uptake of metals by plants from the soil. It is expressed as: $T_{F}=C_{m \text { (plant) }} / C_{M \text { (substrate) }}$ Where $C_{m \text { (plant) }}$ is the measured concentration of metal, $\mathrm{m}$ in plant and $\mathrm{C}_{\mathrm{M} \text { (substrate) }}$ is the measured concentration of bedrock (in this case the limestone, shale substrate) [14). If the Transfer Factor is greater than $1\left(\mathrm{~T}_{\mathrm{F}}>1\right)$ it implies that bioaccumulation or uptake of the specified metal has occurred in the plants. The various $T_{F}$ calculated (Table 3) revealed high uptake of the metals in the various plants analysed. The calculated $\mathrm{T}_{\mathrm{F}}$ revealed that all the plants have bio-accumulated $\mathrm{Pb}$ and $\mathrm{Zn}$, while $\mathrm{Ni}$ was only bio-accumulated by Saccharum officinarum. Mn and $\mathrm{Ba}$ were also selectively bio-accumulated by some of the plants (Table 3 ). The implication of these observed trends in both soils and crops cultivated in vicinity of the Cement factory is an indication that the environmental media (soils and crops) have been greatly impacted. These crops are variably consumed as vegetables in the Ewekoro area and throughout the south-western part of Nigeria. With this bio-accumulation of potentially toxic metals such as $\mathrm{Pb}$, it means that the inhabitants of this area have been consuming vegetables laden with lead without knowing. This has a very grave consequence on public health in the area.

\subsubsection{Potential health implication}

Data collated (Table 4) from the Health Centers around the area showed various prevailing health challenges in the community. A very cursory look at Table 4 revealed that cases of reported health challenges had been on a steady increase from 2008 till 2012 captured in the records evaluated. The worrisome thing is also in the reported cases in Chest Pain, which may be precursors to Cardiac problems in addition to abdominal pains and conjunctivitis. These are all diseases that can be induced one way or the other by the consumption of metal laden foods or exposure to metal laden dusts from the environment. These records can also be under-estimating the health challenges in the area as many more people do not go to seek medical advices or attention due to the cost for treatments from orthodox Doctors thereby resorting to self-medication and unorthodox treatment; such people will definitely not be captured in the analysed data. 


\section{Conclusions}

The soils and crops around the Cement factory in Ewekoro have been studied for selected metal contents and the work showed that these soils have been greatly impacted by the activities of the factory to a level where the health and wellbeing of the inhabitants of the area can be impaired. The interpreted data from the Health Centers also confirm that there is an upward swing in the number of reported cases that may have been induced by the consumption of the crops in this area as well as exposure to the soil and dusts of the area. It is the view of these authors that efforts should be intensified to ameliorate the deteriorating level in the quality of the soils around this Cement factory and the need to encourage the farmers to cultivate crops that may not likely bio-accumulate the metals in the soils as being currently practiced in order to reduce the possible pathway of metal into the food chain of the people in the area.

Table 1: Summary of selected metals in soil and cultivated crops in the study area.

\begin{tabular}{|c|c|c|c|c|c|c|c|}
\hline \multirow[t]{2}{*}{ Metals } & \multicolumn{2}{|c|}{$\begin{array}{l}\text { Soils } \\
\text { (ppm) }\end{array}$} & \multirow{2}{*}{$\begin{array}{c}\text { USEP } \\
\text { A } \\
\text { (Soils) } \\
\text { (ppm) }\end{array}$} & \multicolumn{2}{|c|}{$\begin{array}{l}\text { Plants } \\
\text { (ppm) }\end{array}$} & \multirow{2}{*}{$\begin{array}{l}\text { WHO/ } \\
\text { FAO }\end{array}$} & \multirow{2}{*}{$\begin{array}{c}\mathrm{EC} / \\
\mathrm{CODE} \\
\mathrm{X}\end{array}$} \\
\hline & Range & $\begin{array}{c}\text { Mean } \pm \text { Std. } \\
\text { Dev }\end{array}$ & & Range & $\begin{array}{c}\text { Mean } \pm \text { Std. } \\
\text { Dev }\end{array}$ & & \\
\hline $\mathrm{Cu}$ & $22.0-180.0$ & $67.5 \pm 43.7$ & 30.0 & $2.6-37.0$ & $18.0 \pm 10.4$ & 30 & 0.3 \\
\hline $\mathrm{Pb}$ & $6.0-238.0$ & $47.6 \pm 59.2$ & 10.0 & $0.66-93.0$ & $13.1 \pm 23.7$ & 2 & 0.3 \\
\hline $\mathrm{Zn}$ & $48.0-550.0$ & $170.6 \pm 141.6$ & 50.0 & $14.9-1288.0$ & $180.1 \pm 245.98$ & 60 & $<50$ \\
\hline $\mathrm{Mn}$ & $166.0-1126.0$ & $506.8 \pm 230.7$ & 600.0 & $26.0-6192.0$ & $360.4 \pm 1669.6$ & & \\
\hline $\mathrm{Ba}$ & $24.0-157.0$ & $68.3 \pm 36.0$ & 430.0 & $2.6-403.8$ & $40.1 \pm 109.1$ & & \\
\hline $\mathrm{Cr}$ & $34.0-107.0$ & $64.8 \pm 21.4$ & 100 & $1.2-89.5$ & $21.3 \pm 27.3$ & & \\
\hline $\mathrm{Cd}$ & $0.6-3.3$ & $1.5 \pm 0.9$ & 0.06 & $0.02-2.71$ & $0.33 \pm 0.50$ & & \\
\hline $\mathrm{Ni}$ & $6.0-18.0$ & $12.8 \pm 3.7$ & 40 & $0.3-14.8$ & $2.8 \pm 3.1$ & & \\
\hline
\end{tabular}

Table 2: Calculated contamination factors for the soils in Ewekoro.

\begin{tabular}{|l|l|l|}
\hline Metal & Range of $\mathbf{C}_{\mathbf{f}}$ & Interpretation \\
\hline $\mathrm{Cu}$ & $0.6-21.0$ & Low Contamination to very high contamination \\
\hline $\mathrm{Pb}$ & $3.0-146.0$ & $\begin{array}{l}\text { Considerable contamination to very high contamination } \\
\text { factor }\end{array}$ \\
\hline $\mathrm{Zn}$ & $0.9-32.0$ & Low Contamination to very high contamination \\
\hline $\mathrm{Mn}$ & $1.8-45.0$ & Low Contamination to very high contamination \\
\hline $\mathrm{Ba}$ & $2.2-70.0$ & Moderate contamination to very high contamination factor \\
\hline
\end{tabular}


Table 3: Calculated Transfer Factor for analysed plants in Ewekoro area.

\begin{tabular}{|l|l|l|l|l|l|l|}
\hline Local name & Botanical name & $\mathrm{Pb}$ & $\mathrm{Zn}$ & $\mathrm{Ni}$ & $\mathrm{Mn}$ & $\mathrm{Ba}$ \\
\hline sugarcane & $\begin{array}{l}\text { Saccharum } \\
\text { Officinarum }\end{array}$ & 8.27 & 44.4 & 3.7 & 9 & 3.2 \\
\hline sugarcane & $\begin{array}{l}\text { Saccharum } \\
\text { Officinarum }\end{array}$ & 16.54 & 20.1 & 1.2 & 5 & 36.7 \\
\hline Soko & $\begin{array}{l}\text { Celosia } \\
\text { Argentea }\end{array}$ & 1.64 & 8.6 & 0.5 & 2 & 0.3 \\
\hline Soko & $\begin{array}{l}\text { Celosia } \\
\text { Argentea }\end{array}$ & 3.27 & 3.9 & 0.2 & 0 & 3.4 \\
\hline Cocoyam & $\begin{array}{l}\text { Colocasia } \\
\text { Esculerita }\end{array}$ & 9.8 & 8.3 & 0.8 & 3 & 0.4 \\
\hline Cocoyam & $\begin{array}{l}\text { Colocasia } \\
\text { Esculerita }\end{array}$ & 19.61 & 3.8 & 0.3 & 1 & 4.1 \\
\hline Ewedu & $\begin{array}{l}\text { Corchoruos } \\
\text { Olitorius }\end{array}$ & 3.5 & 5.2 & 2.2 & 7 & 0.3 \\
\hline Ewedu & $\begin{array}{l}\text { Corchoruos } \\
\text { Olitorius }\end{array}$ & 7.02 & 2.4 & 0.7 & 2 & 3.1 \\
\hline
\end{tabular}

Table 4: Summary of health challenges evaluated from medical records.

\begin{tabular}{|l|l|l|l|l|l|l|}
\hline \multirow{2}{*}{ Disease Type } & \multicolumn{6}{|l|}{ Years } \\
\cline { 2 - 7 } & 2008 & 2009 & 2010 & 2011 & 2012 & Total \\
\hline Malaria & 185 & 94 & 166 & 289 & 310 & 1048 \\
\hline Diarrhea & 12 & 19 & 25 & 32 & 41 & 154 \\
\hline URTI & 28 & 25 & 26 & 32 & 93 & 154 \\
\hline Febrile convulsion & 15 & 13 & 19 & 21 & 28 & 96 \\
\hline Abdominal pains & 20 & 21 & 23 & 25 & 25 & 114 \\
\hline Mumps & 5 & 8 & 10 & 15 & 19 & 57 \\
\hline Chest pain & 23 & 25 & 31 & 57 & 62 & 198 \\
\hline Conjunctivitis & 20 & 19 & 16 & 25 & 39 & 119 \\
\hline Hyperthermia & 7 & 9 & 3 & 8 & 7 & 34 \\
\hline Rashes & 12 & 11 & 13 & 12 & 11 & 59 \\
\hline
\end{tabular}

\section{References}

[1] Cement Industry Federation, 2011. www.cement.org.au

[2] Akgüç N, Özyiğit I.I., Yarcı C., Pyracantha coccinea Roem. (Rosaceae) as a biomonitor for $\mathrm{Cd}, \mathrm{Pb}$ and $\mathrm{Zn}$ in Mugla Province (Turkey). Pakistan Journal of Botany 40(4) pp. 1767-1776, 2008.

[3] Huseyinova R., Kutbay H.G., Bilgin A., Kılıc D., Horuz A., Kirmanoglu C. Sulphur and Some Heavy Metal Contents in Foliage of Corylus avellana and Some Roadside Native Plants in Ordu Province, Turkey. Ekoloji 18(70) pp. 10-16, 2009. 
[4] Y1lmaz R., Sakcali S., Yarci C., Aksoy A., Ozturk M. Use of Aesculus hippocastanum L. as a Biomonitor of Heavy Metal Pollution. Pakistan Journal of Botany 38(5) pp. 1519-1527, 2006.

[5] Ozturk M., Yücel E., Gücel S., Sakçalı S., Aksoy. A Plants as Biomonitors of Trace Elements Pollution in Soil. In: Prasad MNV (ed), Trace Elements as Contaminants and Nutrients: Consequences in Ecosystems and Human. John Wiley and Sons, New Jersey, pp. 721-742, 2008.

[6] Yaşar U., Ozyiğit I.I., Serin M. Judas tree (Cercis siliquastrum L. subsp.siliquastrum) as a possible biomonitor for $\mathrm{Cr}$, Fe and $\mathrm{Ni}$ in Istanbul (Turkey). Romanian Biotechnological Letters 15(1) pp. 4979-4989, 2010.

[7] Okafor E., Ch and Opuene K. Preliminary assessment of trace metals and polycyclic aromatic hydrocarbons in the sediments. International Journal of Environmental Science and Technology 4(2) pp. 233-240, 2007.

[8] Mahvi A.H. Application of agricultural fibers in pollution removal from aqueous solution. International Journal of Environmental Science and Technology 5(2) pp. 275-285, 2008.

[9] Akinci I.E., Caliskan U. Effect of Lead on Seed Germination and Tolerance Levels in Some Summer Vegetables. Ekoloji 19(74) pp. 164-172, 2010.

[10] Demirayak A., Kutbay H.G., Kilic D., Bilgin A., Huseyinova R. Heavy Metal Accumulation in Some Natural and Exotic Plants in Samsun City. Ekoloji 20(79) pp. 1-11, 2011.

[11] Dogan M., Colak U. Effect of Lead Applied to Triticum aestivum L. cv. Tosunbey on Some Physiological Characteristics. Ekoloji 19(73) pp. 98-104, 2009.

[12] Kachenko A.G., Singh B. Heavy Metals Contamination in Vegetables Grown in Urban and Metal Smelter Contaminated Sites in Australia. Water, Air, and Soil Pollution 169: 101-123, 2006.

[13] Hakanson, L., An ecological risk index for aquatic pollution control - A sedimentological approach, Water Res. 14, pp. 975-1001, 1980.

[14] Tagami, K. and Uchida, A. comparison of concentration ratios for technetium and nutrient uptake by three plant species. Chemosphere $\mathbf{6 0}$, pp. $714-717,2005$.

[15] US Environmental Protection Agency (USEPA) United States Environmental Protection Agency. Air Pollution Emission Standards and Guidelines for Municipal Waste Combustors. http://www.epa.gov/ air/criteria.html, 2010. 